\title{
Rethinking the Research Agenda
}

\author{
Hilary Perraton
}

\begin{abstract}
Research is seen as something grounded in theory that can lead to improved practice. Without a theoretical basis it is unlikely to go beyond data gathering. The theoretical insights leading to good research are more likely to come from educational and social theories generally than from an attempt to develop a theory of open and distance learning. An examination of existing research shows that it is often atheoretical and predominantly descriptive. Research on the context of open and distance learning, considering its purposes, outcomes, and relevance to major educational problems, has been relatively neglected as contrasted with research on its application. Significant research issues today include: problems posed by globalisation, including issues of governance and consumer protection; ways of maximising public benefit from new communication technologies; the development of strategies for AIDS education; and the continuing need for educational expansion.
\end{abstract}

Research lies midway between the other two themes of this issue - theory and good practice. This paper advances four propositions about the links between them and follows them with four proposals about important areas of research.

\section{Proposition one: research and theory}

First, unless research is grounded in theory, it cannot be much more than data gathering. The development or existence of a theory makes it possible to generate hypotheses about good practice, to frame questions that will test them, and so to develop more soundly based guides to practice. (This assumes that our concern with theory and research is mainly to help solve problems. It may not be. We may be interested in research on education purely in order to widen our understanding of human behaviour. This is a defensible and interesting posture, but not the starting point for the four propositions and suggested research agenda). To illustrate: the International Research Foundation for Open Learning (IRFOL) recently completed a research project for the European Commission on the cost-effectiveness of various technologies used in open and distance learning within European Union member countries. ${ }^{1}$ We wanted to help solve the administrator's problem of choosing between alternative technologies that might include, among others, print, videoconferencing and various 
computer-based approaches. We grounded our methodology in theories that came from learning and from classical microeconomics. From learning, we took as a starting point the theory of media equivalence, that there are no significant differences in teaching effectiveness between different media (cf. Clark, 1983; Perraton, 1987). From classical microeconomics we took well-tried methods for analysing the costs which allowed us to determine some of the conditions under which we might find economies of scale in using the technologies (cf. Jamison, Klees \& Wells, 1978; Jamison, 1982; Orivel, 1987). This work in turn led us to develop a number of propositions to guide practice; the research suggests, for example, that it there is always an onus upon the course designer to justify the use of any medium other than print, so that the costs of print can be regarded as a default option, and that, if lecturers are to be employed at each location and we neglect the opportunity costs of student time, then videoconferencing is always more costly than face-to-face education (Hülsmann, 2000). Neither proposition is earth-shattering but they serve to illustrate the nexus between problem, theory, research and good practice.

\section{Proposition two: traditions of educational think- ing}

They take us to the second proposition, that theoretical insights are more likely to be found from a range of educational and social theories than from attempts to develop theories of open and distance learning. Four traditions of educational thinking illustrate the argument. Caricaturing them only slightly, we could label them the Jencks thesis, the Rutter argument, the learning theory approaches, and the neo-marxist tradition. An excursion among the traditions helps illuminate the strengths and weaknesses of research within open and distance learning.

In his examination of American education, Jencks found that, despite the American dream and mythology, education was singularly ineffective in promoting equality. He concluded that, "as long as egalitarians assume that public policy cannot contribute to economic equality directly but must proceed by ingenious manipulations of marginal institutions like the schools, progress will remain glacial" (Jencks, 1973, p. 265). This reads like a counsel of despair for egalitarian educators. But his arguments can be used to generate research questions for those who argue that open and distance learning has particular strengths in widening access asking, for example, 'how if at all can distance-teaching institutions redress the structural inequalities that mark much conventional education?'.

In their opening chapter Rutter and his colleagues refer to the apparent conflict between Jencks' conclusions and their own work on the effects of secondary education in London. Rutter and his colleagues found that:

International Review of Research in Open and Distance Learning 
schools do indeed have an important impact on children's development and it does matter which school a child attends. Moreover, the results provide strong indications of what are the particular features of school organisation and functioning which make for success. (Rutter, Maughan, Mortimore \& Ouston, 1979, p. 1).

Using the title of another book in the same tradition, School Matters (Mortimore, Sammons, Stoll, Lewis, \& Ecob, 1988), their findings suggest that one may seek to identify the features within the process of education that are likely to correlate with successful or unsuccessful outcomes Within open and distance learning there is, similarly, a vein of research that suggests changes in methodology, usually in terms of instructional design or student support, that will improve outcomes. As we will see below, the vein is surprisingly narrow.

Learning theories, which seek to specify the conditions under which learning is enabled or hindered, have been used as the starting point for some research and practice in open and distance learning. In his examination of the issue, and drawing on the work of Bruner, Gagné, Ausubel and Bààth in particular, Holmberg (1995) concluded that "distance education and thinking about distance education are firmly based in general educational theory" (p. 160). In a more imaginative approach, and suggesting a programme of research that no-one, sadly, has picked up since he died, Lewis (1973) sought to set up a theoretical framework to help solve "hard practical problems of course design" (p. 197) that would encourage students to develop higher-order problem-solving skills and enable them "to challenge and extend and even transform the knowledge [they are] ... given" (p. 203).

Within the neo-marxist tradition, education is seen as an activity which reinforces and helps reproduce existing social structures but contains internal contradictions between the free examination of ideas necessary for effective education and the interests of the capitalist state and, potentially at least, between the teaching profession as an interest group and other elements within society (cf. Bowles \& Gintis, 1976). This analysis might lead us to conclude that open universities, for example, are a powerful device for containing educational demand at modest cost and so allowing more conventional universities to continue in their traditional role (cf. Perraton, 2000, pp. 198-90). The research questions we derive from the tradition will depend on our own political stance. If, at one extreme, we have an instrumental view of training to meet labour-market demands, we may want to discover how to design a distance-learning system that satisfies an employer's needs while discouraging labour mobility. At the other, we may ask how open and distance learning can be deployed to exploit the contradictions inherent to the educational system in the interests of seeking a more equitable society.

We could go on, seeking to generate other important questions from standpoints within sociology and political science among other domains as well as from ed-

International Review of Research in Open and Distance Learning 
ucation. Morgan (1996), for example, pointed out the relevance of the work of Rogers, Bruner and Giddens to research on open and distance learning. One point of the excursion is to show that existing theory will help us in framing questions that matter and therefore of value in seeking answers that will improve practice. More than that, it suggests that social literature generally is more useful than much of the discourse within open and distance learning. There, for example, we have much concern with definitions. Holmberg, for example, in his epitomizing theory presentation, seems deeply concerned to differentiate distance education from other forms of education, even though he does go on to seek refutable hypotheses that may follow from it $(1995$, p. 175, 181). Keegan argues that "a firmly based theory of distance education will be one which provides the touchstone against which decisions ... can be taken with confidence" (Holmberg, 1995, p. 157). But when he comes to set out his own theoretical propositions they are in forms such as: "It is hypothesized, therefore, that distance students have a tendency to drop out in those institutions in which structures for the reintegration of the teaching acts are not satisfactorily achieved" (Keegan, 1996, p. 120). The caution in the second half of the sentence makes it look like what Lakatos (1980) derided as degenerative problem shift and severely limits its capacity to provoke good research questions. The excursion also serves to remind us that good research does not need to begin with theory. Indeed, as argued below, much of it will begin with a problem. But we need then to know what our theoretical starting point is in order to design and justify our research approach.

\section{Proposition three: about the existing research}

The discussion so far suggests that research in open and distance learning needs to be grounded in theory, that there are often benefits in drawing theory from outside narrow educational confines, and that research will suffer unless this is done. An examination of existing research literature confirms that much of it suffers from an apparently atheoretical approach. In a review we did before launching the International Research Foundation for Open Learning we found that most research fell under five headings:

1. Description. There are many descriptive accounts of courses and institutions. Indeed the bulk of the literature on open and distance learning, whether specifically labelled as research or not, is essentially descriptive, discussing some combination of management, students, teaching methods and outcomes of a course or institution.

2. Audience studies. We have many studies of the audiences for open and distance learning .... In some cases these studies also examine the performance of students in relation to variables associated with the methods of study.

International Review of Research in Open and Distance Learning 
3. Cost-effectiveness studies. There is a growing literature on cost-effectiveness with a fair measure of commonality in the methodology used....

4. Methodology. There are studies, again often descriptive, of the various methods used to teach, support and counsel open and distance-learning students....

5. Social context. Some recent work has been concerned to examine the social context of open and distance learning. (Perraton, 1997, pp. 17-18)

If it were not so predominantly descriptive one might claim that the second group of studies were implicitly accepting a Jencksian view of the educational world, assuming that the important thing was to know our audience and that the fourth were following the Rutter approach in looking at variables in process. But in practice few studies begin even by genuflecting towards theory and, in consequence, make it the more difficult to draw any general conclusions. More than that, our third proposition is that where research has gone beyond description towards explanation, it has tended to be about the application of open and distance learning rather than about its context. In the same report we used the term "application" for questions of methodology and "issues about the most appropriate ways of using open and distance learning for a given audience and purpose" (Perraton, 1997, p. 19). In contrast questions about context

concern the purposes for its use, its role alongside other forms of education and its outcomes. The questions cluster around issues about the legitimacy, quality, effectiveness and outputs of open and distance learning that are particularly significant for policy makers (p. 19).

As a result of these biases, we are short of well-founded research findings on many aspects of open and distance learning, while findings about its context, critical for policy makers, are especially scarce. At the same time there are plenty of problems. Just on applications - not the main theme of this paper - for example, problems of choice of methodology arise because we have little more than rules of thumb to guide us on key issues like media selection, the case for combining media (always asserted, but barely established), and instructional design (discussed further in Perraton, 1995, pp. 16-17). More specifically, and to illustrate, we know that the methods of open and distance learning lend themselves to rote learning. We should be able to develop research strategies that started with the kind of hierarchy of learning proposed by Gagné and ask how one would research approaches designed to achieve learning at the upper end of the hierarchy. 


\section{Proposition four: research on context as well as application}

The fourth proposition is that the more important and more difficult part of the agenda is about context. It needs to be grounded in theory and grapple with the major educational problems that confront us. At the recent World Education Forum in Dakar the emerging new contexts for educational development and expansion were seen as including:

- the political, social and economic shifts in Eastern and Central Europe;

- the rapid development of the Internet as a pervasive lever of change for the organisation of life, commerce, entertainment and education;

- the emerging new economy based on intangible capital and calling for much increased adaptability to rapid change and a new repertoire of entrepreneurial capabilities and attitudes.

- ... and in some regions ... the disastrous spread of the HIV-AIDS pandemic (Skilbeck, 2000, p. 14)

If open and distance learning is to play more than a peripheral role in education we should therefore expect its research agenda to address issues that follow from these changes such as the role of private and public sector institutions in a world of neoliberal hegemony, the gap between the information-rich and the information-poor, educational responses to HIV-AIDS and, of course, educational expansion. We look at each in turn. They are briefly spelt out in order to establish that each of them demands more attention, and a higher priority from distance education researchers, than the audience studies and descriptive accounts, or the development of how-to-do-it guides on the application of distance education.

\section{Four areas worth researching}

A generation back, social theory argued that market forces had no good part to play in the social sector and that their effects were likely to be malign. Titmuss demonstrated this in his classic comparison between the safe, voluntary-based supply of blood to hospitals in Britain and the, inferior, pay-basis supply in the United States (1970). In her debunking of the Famous Writers School,

Jessica Mitford quoted counsel for the Federal Trade Commission's Bureau of Deceptive Practices who argued "there is a basic contradiction involved when you have profit-making organizations in the field of education" (Mitford, 1979, p. 169). These views no longer represent a social consensus. At the same time,

International Review of Research in Open and Distance Learning 
the new technologies have made it easier for distance-teaching institutions to operate internationally, even globally. Mitford's work showed that there never were adequate constraints on sharp practice even within frontiers. Within public sector higher education, the community of scholars has traditionally controlled quality but conventional structures do not operate easily at a long distance; some universities have sought to bypass their regular systems of checks and balances in order to operate internationally and competitively. ${ }^{2}$ One part of a broad set of problems about the intersection of the public and private sector is easy to define: given globalisation, how can we establish systems of governance and regulation that will protect individuals with imperfect information who are seeking to enrol in courses available at a distance? (It matters both to the individuals and to bona fide institutions where an educational Gresham's law may operate, allowing bad institutions to undercut and drive out good). We probably need to draw from political science in order to generate the research questions about governance needed to help answer this question, chosen to illustrate the range of problems facing educators and the public in a changed political environment.

Globalisation sets the context for the next set of issues about the gap between the information-rich and the information-poor. The problem was identified in the Briggs report (1987), which set out the proposals for what became the Commonwealth of Learning. It argued that while "the new communications technologies make it possible for learners to have access to the world's knowledge no matter where they live" there remained a danger that "there could be an even further widening of the gap between rich countries and poor in their access to information" (Briggs, et al., 1987, p. 8). The development of the Internet has since dramatised the differences and at the same time revealed a further problem within the problem - of differential access to communication media between town and country. Some of the issues here are conceptually simple about the allocation of resources to new and old technologies - though they may be politically tricky: within the United States "while textbooks ran chronically short in poor school districts, and while some 200 traditional colleges shut their doors over the decade to 1997, politicos and corporate executives prattled on about the need to wire up additional 'cyberschools"' (Schiller, 1999, p. 200). Others are more complex involving curricular and economic questions about the educational purpose of particular types of investment in technology, and the educational outcomes that may be expected from that investment. Again we are short of research data, especially about developing countries. ${ }^{3}$ But the issues are stark: how, through research, can we find ways of maximising public and international benefits from the new information opportunities?

An African consultation on education for all identified the third theme:

1. The EFA 2000 Conference recognises that HIV/AIDS has the potential to undermine much that education seeks to achieve as well as the education system itself.

2. The conference also recognises that there is little systematic information

International Review of Research in Open and Distance Learning 
on how the education sector can cope with the pandemic, reduce its further spread and lessen its impact. (RTAG Secretariat, 2000, p. 26)

The African meeting went on to recommend that HIV-AIDS should become a major theme, along with five more specifically educational ones, for the Dakar world conference. Existing theory and research can go some way towards developing the strategies called for by the African meeting. Demographic modelling should make it possible to calculate the effects of AIDS on teacher recruitment and supply; work on the multistep theory of human communication suggests ways of using the mass media for health education (Rogers, 1971); a thorough study of communication-based education in agriculture and nutrition summarises what we know about nonformal education programmes (Hornik, 1988). Together these suggest that it should be possible to set up programmes, incorporating formative evaluation and research, that integrate mass-communication programmes of education with practical activities including the distribution of condoms. In learning from such a programme the researcher would need to draw both from the traditions and assumptions of action research but also insights from sociology and social psychology on the religious and cultural obstacles in the way of AIDS education and containment.

On educational expansion we come back to the more conventional educational research agenda. Two specific issues look among the most important. First, what are the most appropriate structures that will help governments expand effective university education in the south? Second, can we devise structures for junior-secondary education that will harness open and distance learning to meet the new demands that are following, and will follow, the earlier expansion of primary education? In both cases, the record of experience is patchy, with many called to nonconventional education but few chosen to succeed. We have ample descriptive literature on open and distance learning at both levels of education and summaries of what can be learned from it (cf. Perraton, 2000). Perhaps to tackle the real problems that follow from the modest achievements of the existing programmes we need to begin by asking about the nature of the learning process and the difficulties faced by relatively unsophisticated learners. Or we need to address the political issues that would be involved in mixing and matching education on and off-campus so that all students study partly in each mode. Or: the plea is for hard thinking, and good research questions, that will result in findings to help better practice.

\section{Conclusion}

Education can help us to a better world. It will help us get there if we rely more on good research and less on under-informed trial and error.

International Review of Research in Open and Distance Learning 


\section{References}

Bowles, S. and Gintis, H. (1976). Schooling in capitalist America: Educational reform and the contradictions of economic life. New York: Basic Books.

Briggs, A., Adesola, A., Christodoulou, A., Crocombe, M., Nettleford, R., Reddy, G. R., Rickett, R., Watts, R. L. \& Williams, B. (1987). Towards a commonwealth of learning: A proposal to create the University of the Commonwealth for Co-operation in Distance Education: Report of the expert group on Commonwealth co-operation in distance education and open learning. London: Commonwealth Secretariat.

Clark, R. (1983). Reconsidering research on learning from media. Review of Educational Research, 53(4), 445-459.

Holmberg, B. (1995). Theory and practice of distance education (2nd ed.). London: Routledge.

Hornik, R. C. (1988). Development communication. New York: Longman.

Hülsmann, T. (2000). The costs of open learning: A handbook. Oldenburg: Bibliotheks- und Informationssystem der Universität Oldenburg.

Jamison, D. T. (1982). An introduction to the methods of cost analysis. In H. Perraton (Ed.), Alternative routes to formal education: Distance teaching for school equivalency. Baltimore: Johns Hopkins University Press.

Jamison, D. T., Klees, S. J. \& Wells, S. J. (1978). The costs of educational media: Guidelines for planning and evaluation. Beverly Hills: Sage.

Jencks, C. (1972). Inequality: A reassessment of the effect of family and schooling in America. London: Allen Lane.

Keegan, D. (1996). Foundations of distance education (3rd ed.). London: Routledge.

Lakatos, I. (1980). The methodology of scientific research programmes. Cambridge: Cambridge University Press.

Lewis, B. N. (1973). Educational technology at the Open University: An approach to the problem of quality. British Journal of Educational Technology $3(4), 188-203$.

Mitford, J. (1979). Poison penmanship: The gentle art of muckraking. New York: Knopf.

Morgan, A. R. (1996). Still seeking the silent revolution? Research, theory and practice in open and distance education. In T. Evans, V. Jakupec, \& D. Thompson (Eds.), Research in distance education 4, (pp. 7-17). Geelong: 
Deakin University Press.

Mortimore, P., Sammons, P., Stoll, L., Lewis, D. \& Ecob, R. (1988). School matters: The junior years. London: Open Books.

Orivel, F. (1987). Costs and effectiveness of distance teaching systems: A methodological approach. (mimeo) Dijon: IREDU: Université de Bourgogne.

Perraton, H. (1987). Theories, generalisation and practice in distance education. Open Learning 2(3), 3-12.

Perraton, H. (1995). A practical agenda for theorists of distance education. In F. Lockwood (Ed.), Open and distance learning today. London: Routledge.

Perraton, H. (1997). International research in open and distance learning: Report of a feasibility study. Cambridge: International Research Foundation for Open Learning.

Perraton, H. (2000). Open and distance learning in the developing world. London: Routledge.

Perraton, H. \& Creed, C. (2000). Applying new techniques and cost-effective delivery systems in basic education (Education for all 2000 assessment: Thematic study). Paris: UNESCO.

Rogers, E. M. (with Shoemaker, F. F.). (1971). Communication of innovations. New York: Free Press.

RTAG Secretariat (2000). Report on the all sub-Saharan conference on education for all. Harare: UNESCO.

Rutter, M., Maughan, B., Mortimore, P., \& Ouston, J. (1979). Fifteen thousand hours. London: Open Books.

Schiller, D. (1999). Digital capitalism: Networking the global market system. Cambridge Mass: MIT Press.

Skilbeck, M. (2000). Global synthesis (Education for all 2000 assessment). Paris: UNESCO.

Titmuss, R.M. (1970). The gift relationship: From human blood to social policy. London: Allen and Unwin. 


\section{Endnotes}

1. Here and elsewhere I follow European practice in using the term "open and distance learning" as an overall term (cf. Perraton, 2000, pp. 13- 14).

2. At the annual conference of the Higher Education Research and Development Society of Australasia in 1997 I heard a speaker from one publicly funded university boast that, in the interests of speed, entrepreneurship and an overseas deal, she had found a way round the normal university procedures that controlled quality.

3. Some of the findings are summarised in Perraton and Creed (2000). But the answers to quite simple questions - like why did Britain invest the sums she did in information technology in school - are often far from clear and rarely if ever answered explicitly.

Citation Format

Perraton, Hilary. (2000) Rethinking the Research Agenda. International Review of Research in Open and Distance Learning: 1, 1. http://www.icaap.org/iuicode?149.1.1.1 